\title{
ERJ
}

Engineering Research Journal

Faculty of Engineering

Minoufiya University

\section{CONTRACTOR EQUIPMENT MANAGEMENT PRACTICES}

\author{
E. M. Elkassas ${ }^{1}$, M. A. EIganainy ${ }^{2}$, H. H. Elammary ${ }^{1}$ \\ 1. College of Engineering \& Technology-Arab Academy for Science \& \\ Technology \& Maritime Transport. \\ 2. Faculty of Engineering, Irrigation Engineering \& Hydraulics Department, \\ Alexandria University.
}

\begin{abstract}
A heavy construction contractor's success in winning contracts and performing them at a profit is determined by two vital assets, his managerial, technical staff and his equipment. To be competitive in an economic sense, a contractor's equipment spread must be cost effective, both mechanically and technologically. In order to gain insight into the current equipment practices of medium to large size irrigation construction firms, field survey has been conducted during the period (2004-2005), [3]. This paper presents the results of this field survey which serves to identify some of the weaknesses in current equipment management practices for excavation and earth moving in construction of canals and drains .

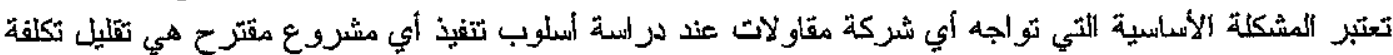

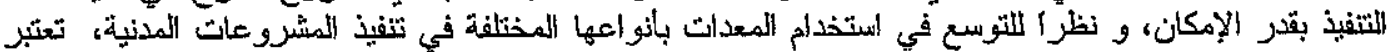

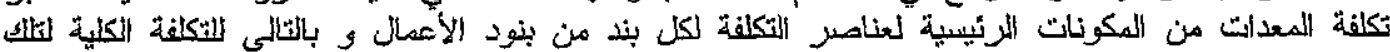
المثروعان.

عند نقير تكلفة المعداتث اللازمة التنفيذ أحد بنود الأعمال تبرز العديد من الأسئلة الهامة والثي يجب الإجابة عنها على النحو الثنالي:

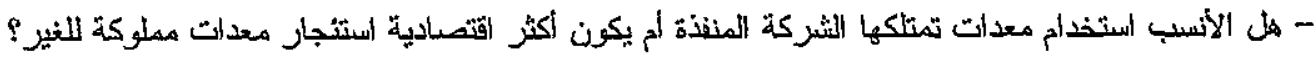

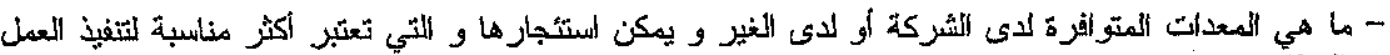

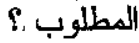

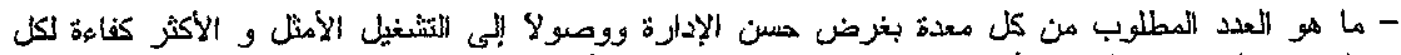

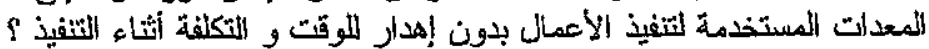

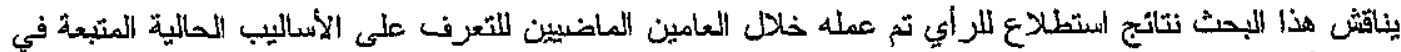

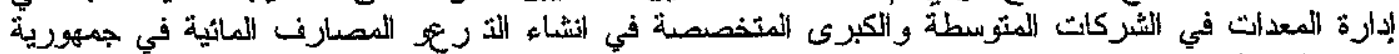

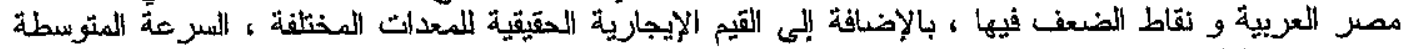

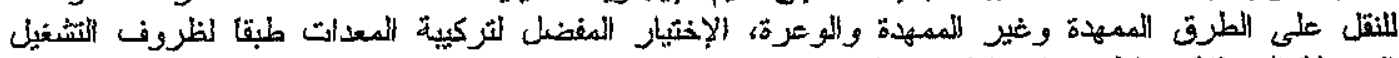

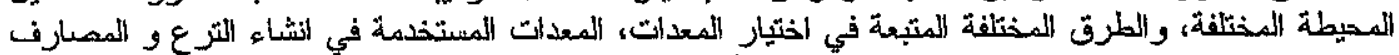

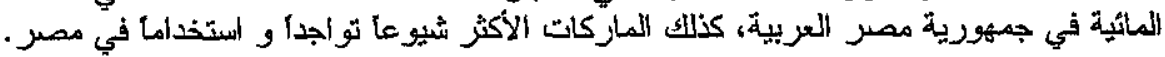

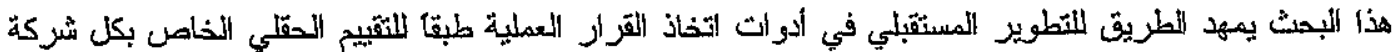

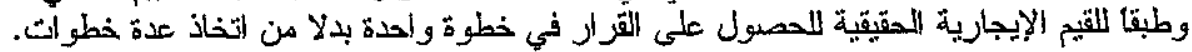

Keywords: Field, surveying, questionnaire, equipment, management, canals, drains.

\section{FIELD SURVEYING}

A special questionnaire is designed to carryout the required field survey. It covers the following purposes:

1. To gain insight into the current equipment practices for medium to large size irrigation construction firms.

2. To facilitate comparisons, to aid in the identification of trends, and to identify current industry practice in regard to selected aspects of equipment ownership, record keeping, equipment retention periods.

3. To determine equipment rental value for different equipment per hour, day, and month.

4. To determine selection methods for proper equipment, preferable equipment in different cases.

5. To determine common speed for hauling units.

6. For recognition of replacement decision factors, replacement decision making practice. 
7. To determine available and common excavation and earth moving plant in Egypt.

The questionnaire is distributed on preselected eleven highly reputation contractors working in construction of irrigation canals and drains in Egypt. Completed questionnaires were received from nine companies, i.e. $80 \%$ return rate.

The replies are analyzed on the following pages and are believed to be indicative of current practice by construction firms in the medium to large size range. Personal interviews with other contractors also produced data compatible with that obtained data in the questionnaires.

To evaluate information produced by participating firms in our survey, the following four questions were imposed on the volume of firms and its classification according to the Egyptian Union for Construction contractors and builders, foundation age, and number of executed construction projects for both irrigation field and other fields which conclude large quantity of excavation and earth moving activities,

1. What is the foundation age for your company?
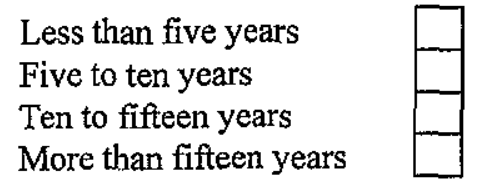

2. How many projects relevant to construction of irrigation canals and drains have been executed by your company? And what is it?

One project
two projects
Three projects
More than three projects
None is relevant

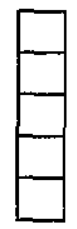

3. How many projects irrelevant to construction of irrigation canals and drains have been executed by your company, which large quantities of excavation and earth moving have been implemented? And what is it?

One project
two projects
Three projects
More than three projects
None is relevant

4. What is the company's classification rank according to The Egyptian Union for Construction contractors and builders?



Results are presented in Figs. (1) to (3)



Figure (1) Foundation age for survey's participating companies

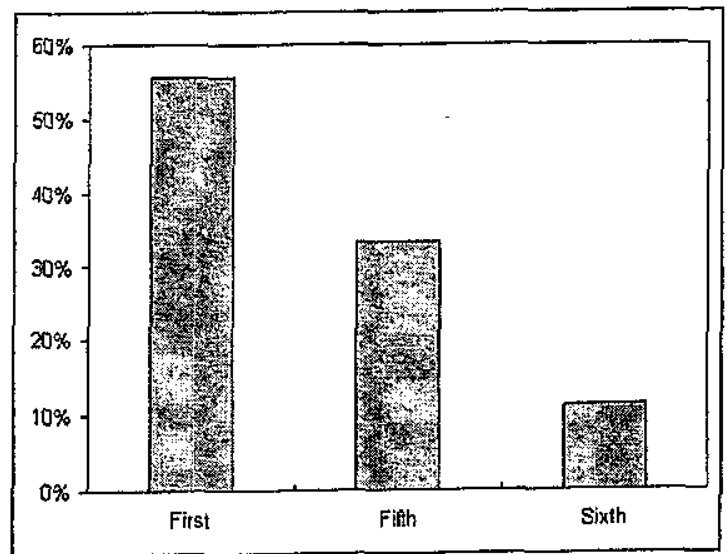

Figure (2) Egyptian Union classification for survey's participating contractors.

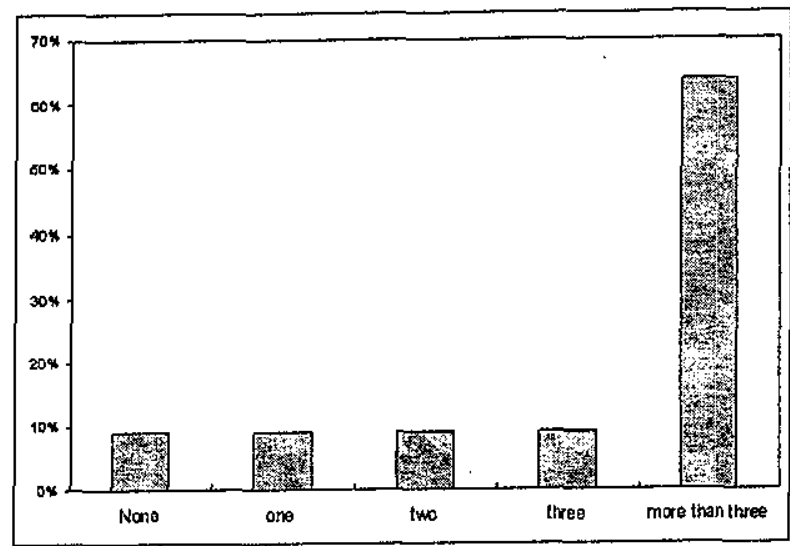

Figure (3) Number of Irrigation projects for survey's participating companies.

To facilitate comparisons and to aid in the identification of trends, twenty one questions were imposed. Present survey sought to identify current industry practice in regard to selected aspects of equipment ownership, record keeping, preferable equipment in different cases, equipment rental value for different equipment per hour, day, and month, selection method for proper equipment, common speed for hauling units, recognition of replacement decision factors, replacement decision making 
practice, equipment retention periods, available and common excavation and earth moving plant in Egypt were the major areas investigated.

While it was evident that many contractors realized the advantage of rationally analyzing real cost data instead of relying on intuition to arrive at an equipment management decision. The majority of firms still depend upon "rules of thump" when it comes to a final assessment.

The validity of contractor supplied equipment data is doubtful in some cases, as evidenced by the discrepancies among answers to multiple questions aimed at the same major theme. Lack of factual information and of knowledge concerning the proper application of economic theory in an analysis emerge as the two major reasons contractors continue their heavy reliance on experience when making machine replacement decisions. The results of decisions based on experience instead of on facts are attested to by the extreme ranges in machine service periods reported even when consideration is given to the fact that different types of contractor specialization impose consequential differences in frontline production equipment and resulting optimum service lives, the reported ranges in equipment retention can not be explained rationally.

\section{EQUIPMENT SERVICE LIVES}

To gather data on a company's retention practice for eight different items of equipment, the following 5th question were imposed:

1. Based upon your company's experience, what are the normal retention periods for the following types of equipment?

1. Elevated scrapers.

2. Back hoes.

3. Face shovels.

4. Dump trucks or Lorries.

5. Bulldozers.

6. Loaders.

7. Graders.

8. Cranes.

This information was collected in both operating hours and calendar year bases

- A trend of retention period varies between 8 to 35 years, or 10000 to 25000 working hours was evident in all classifications common.

- Replies in every equipment class exhibited significant differences between the reported high and low retention periods. It is evident that companies vary greatly in their respective judgments concerning optimum replacement timing.

\section{EQUIPMENT COMMONLY USED IN EGYPT}

The survey's $1^{\text {st }}$ and $15^{\text {th }}$ questions sought data on all equipment used in construction of irrigation canals and drains, the following questions were imposed:

What is the type of available construction equipment - Which owned to your organization?

\begin{tabular}{l|l|} 
Back hoes & \\
Face shovels & \\
Loaders & \\
Dump trucks or Lorries & \\
\cline { 2 - 2 } Elevated scrapers & \\
Graders & \\
Bulldozers & \\
Cranes &
\end{tabular}

- Are there another type of equipment which used in excavation and earth moving in your organization? The results are presented in Fig. (4)

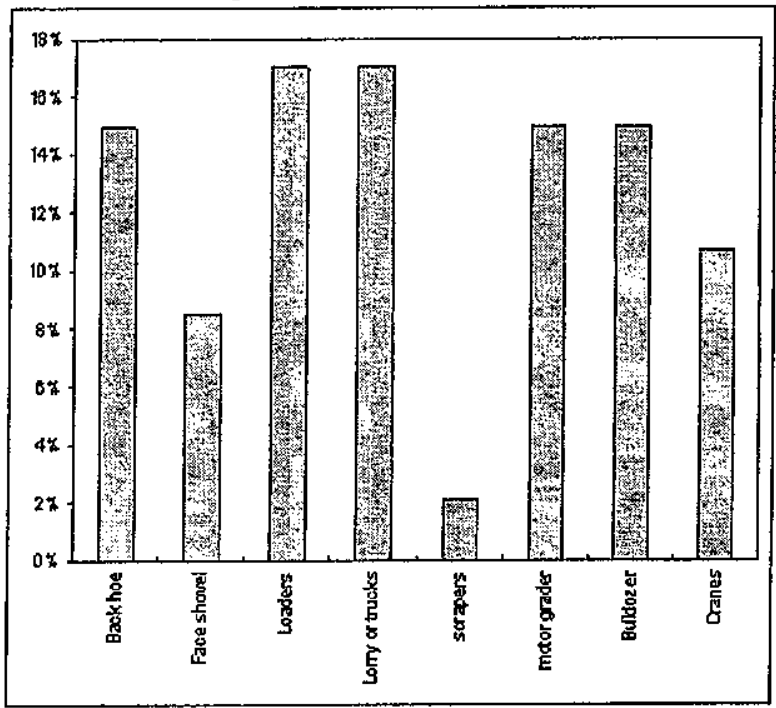

Figure (4) Percentage of available construction equipment which used in construction of irrigation canals \& drains

\section{EQUIPMENT UTILIZATION DECISIONS}

An attempt to discover how companies were arriving at their utilization decision the following $2^{\text {nd }}, 6^{\text {th }}, 7^{\text {th }}$, and $16^{\text {th }}$ questions were imposed:

- For the following site conditions:

1. Narrow site.

2. Wide site.

3. When excavated surplus is used as backfilling material inside site.

4. When excavated materials are stockpiled inside site.

5. For small hauling distance.

6. For large hauling distance.

7. For excavation under ground water table.

8. For excavation above ground water table. 
- What is the preferable excavation equipment from the following choices?

\section{a- Scrapers b- Back hoes c- Face shovels}

- What is the equipment selection method for different jobs in your organization?

By experience (rules of thumb)

Using production rate for each equipment

Using the manual of each equipment

all methods mentioned before

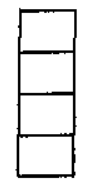

- For the following site conditions:

1. Narrow site.

2. Wide site.

3. When excavated surplus is used as backfilling material inside site.

4. When excavated materials are stockpiled inside site.

5. For hauling to outside the site:

a. For distances $200 \mathrm{~m}-500 \mathrm{~m}$.

b. For distance $500 \mathrm{~m}$

c. For distance $1000 \mathrm{~m}$.

d. For distance $2000 \mathrm{~m}$.

e. For distance $>200 \cdot \mathrm{m}$.

6. For excavation with water existence.

7. For excavation above ground water table and dry excavation.

8. Unmaintained haul route.

9. Maintained haul route.

10. Steep inclined road.

11. Channel's bed is $2 \mathrm{~m}$ wide.

12. Channel's bed is $3 \mathrm{~m}$ wide.

13. Channel's bed is $4 \mathrm{~m}$ wide.

14. Channel's bed is $5 \mathrm{~m}$ wide.

15. Channel's bed is $6 \mathrm{~m}$ wide.

16. Channel's bed is $7 \mathrm{~m}$ wide.

17. Channel's bed is $8 \mathrm{~m}$ wide.

18. Channel's depth is $4 \mathrm{~m}$ height.

19. Channel's depth is $5 \mathrm{~m}$ height.

20. Channel's depth is $6 \mathrm{~m}$ height.

21. Channel's depth is $7 \mathrm{~m}$ height.

22. Channel's depth is $8 \mathrm{~m}$ height.
, choose the preferable earth moving combination from the following three choices:

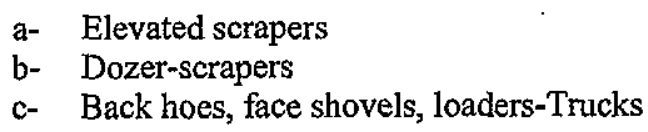

- For the following types of soil and water existence:

1. Sandy soil with water.

2. Dry sand.

3. Clayly soil with water.

4. Clayly soil without water.

5. Boulders \& cobbles with water.

6 . Boulders \& cobbles without water.

7. Blasted rock with water.

8. Blasted rock without water.

9. Muddy soil with water.

10. Muddy soil without water.

, what is an optimal combination of equipment from the following three choices:
a- Elevated scrapers
b- Dozer-scrapers
c- Back hoes, face shovels, loaders-Trucks

Results are represented in the following Figs.(5) to (7).

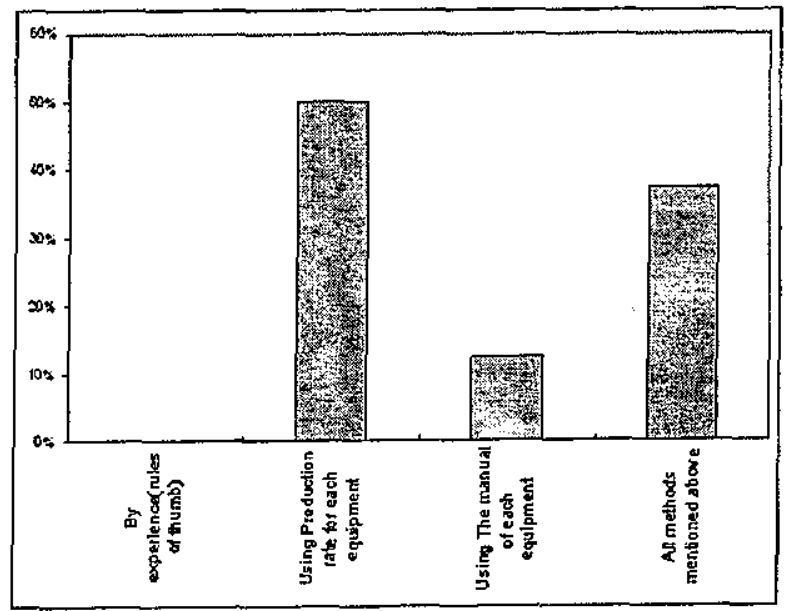

Figure (5) Distribution percentage of equipment selection methods.

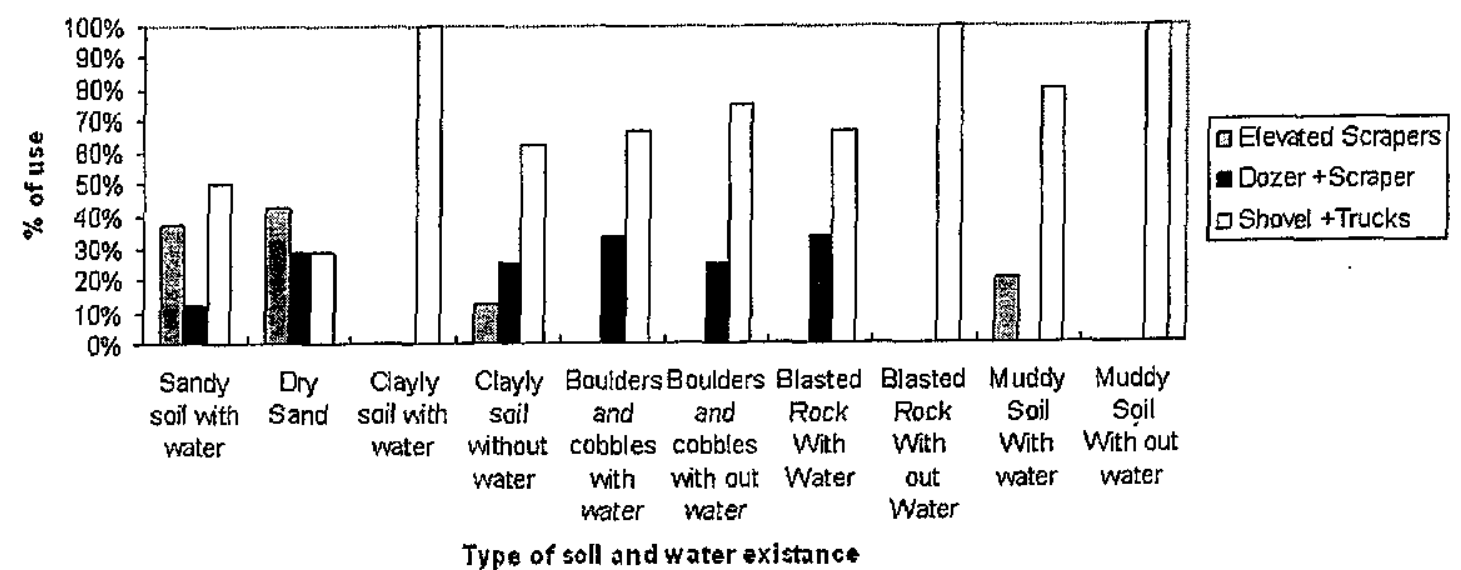

Figure (6) optimal equipment combination for different type of soil and water existence 


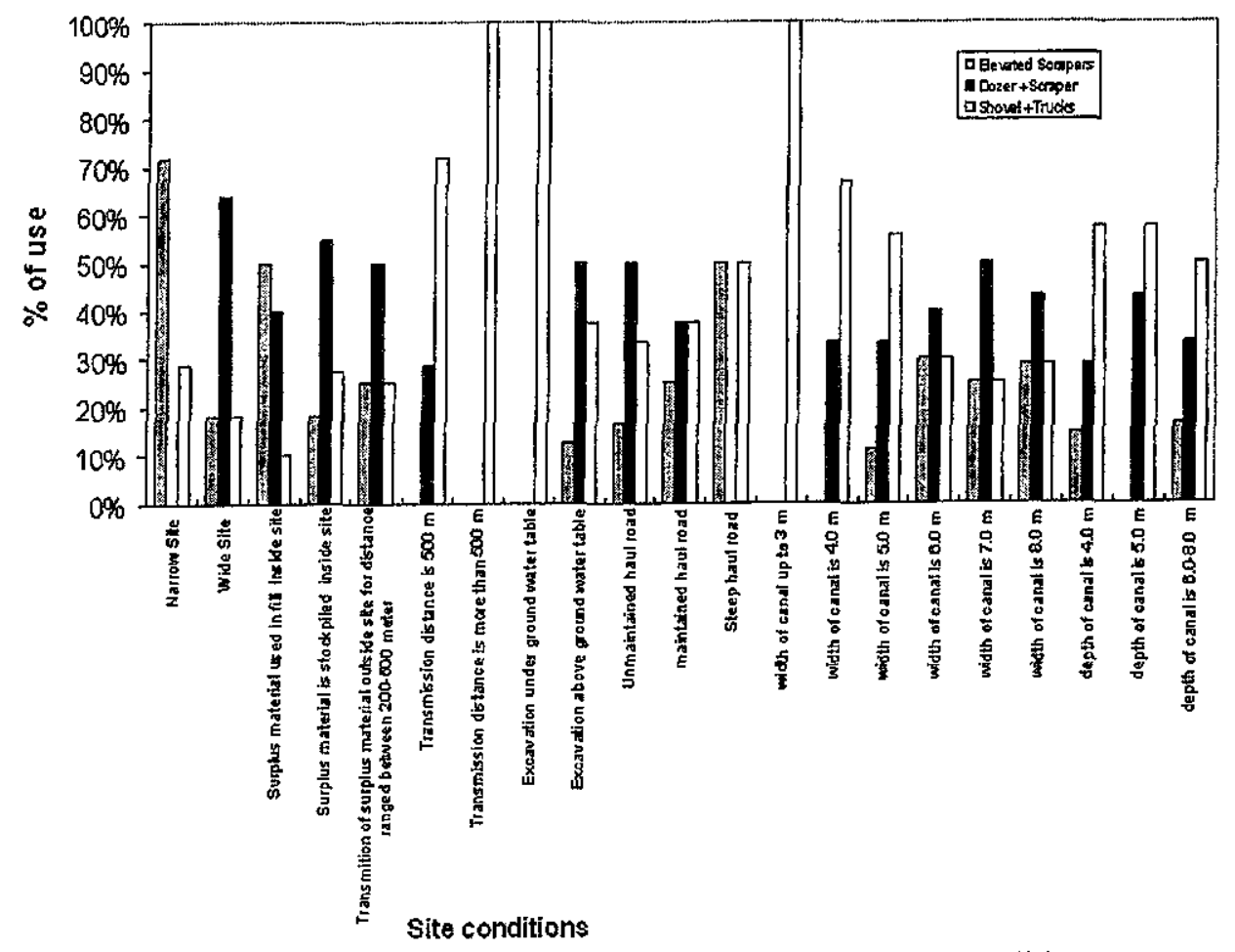

Figure (7) optimal equipment combination for different site conditions

In spite of existence of elevated scrapers and Bulldozer - scraper combination in results of survey ,but all firms agreed with the fact that in recent time these equipment are rarely to be occupied in such industry since in last ten years because of using sprinkler system -trikkle or drip irrigation method instead of using surface system which need to levelling of irrigated area, and no one still using these equipment except who owns big number of it, and never rent it to others.

Shovel-truck combination almost cover all cases and site conditions and different types of soil, accordingly we will concentrate in research upon that common combination

\section{DIMENSIONAL RELATIONS BETWEEN EXCAVATING MACHINE AND CANAL}

An attempt to discover dimensional relations between boom length, channel bed width and its depth. The following $12^{\text {th }}$, and $13^{\text {th }}$ questions were imposed,

- From your experience, what is the optimum boom length, channel depth ratio?

\section{Twice times}

2.50 times

Three to five times

Five to seven times

Seven to ten times

No certain relation
- And, What is the optimum boom length, channel bed width ratio?
Five times
Seven times
Ten times
Fifteen times
Twenty times
No certain relation

Results are represented in Figs.(8),(9).

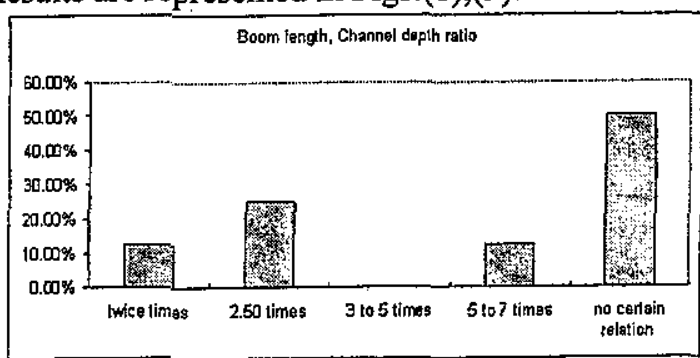

Figure (8) The Boom length-channel depth ratio

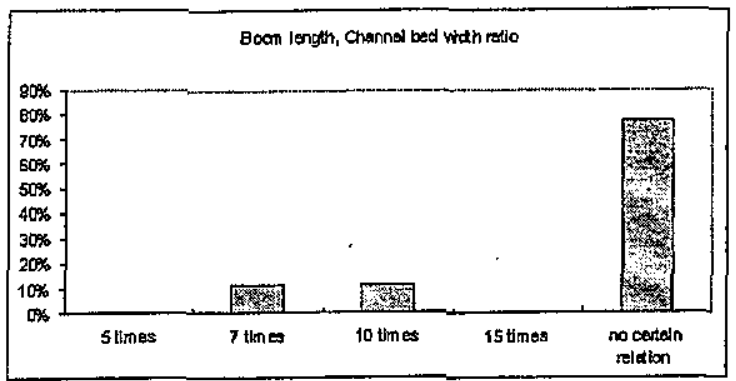

Figure (9) The Boom length-channel bed width ratio 


\section{RATIO BETWEEN BUCKET SIZE OF EXCAVATION MACHINE AND HAULING UNIT}

An attempt to discover dimensional relations between bucket and truck capacity, the following $9^{\text {th }}$ question was imposed,

- From your experience, what is the optimum Truck size- Bucket size ratio?

Three to ten times

No certain relation

Results are represented in Fig. (10).

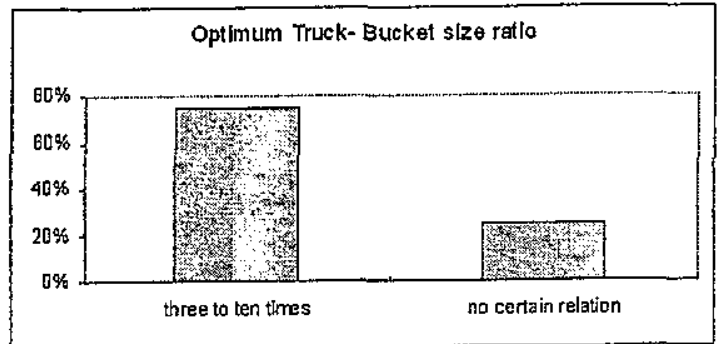

Figure (10) Truck-bucket size ratio

\section{PREFERABLE CHOICE BETWEEN USING}

LARGE SIZE HAULING UNIT WITH SMALL NUMBER OR SMALL SIZE HAULING UNIT WITH BIG NUMBERS

An attempt to discover the preferable choice for different contractors, the following $10^{\text {th }}$ question was imposed,

- If you have the choice to choose, what is your selection from the following choices?

Large size/small number of trucks

Small size/ big number of trucks

No certain relation

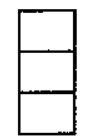

Results are represented in Fig.(11).

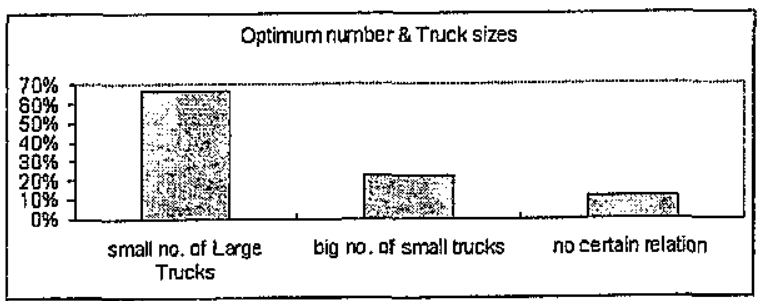

Figure (11) Optimum number and truck sizes

\section{EXCAVATORS PRODUCTIVITY DIFFERENCE FOR TRACKS OR WHEELS MOUNTING}

An attempt to discover relations between productions rates of commonly excavators used in irrigation field which mounted on tracks or wheels for the same type in general conditions of soil, the following 11th question was imposed,

- In your opinion what is the difference in production rate between track mounted excavator, and wheel mounted excavator, (for the same type and horse power), expressed as a percentage?

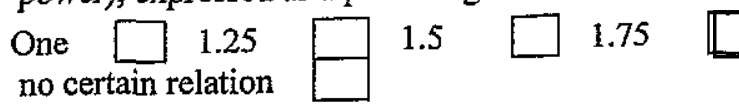

Results are represented in Fig. (12).



Figure (12) Excavator's Track/Wheel mounted production rate ratio

\section{LOADER AND. EXCAVATOR COMBINATIONS}

An attempt to discover the reasons to use loader beside shovel to perform certain task, the following $8^{\text {th }}$ question was imposed,

-In your opinion, when you suggest to use Loader beside excavator in loading trucks?

In general results showed that combination increases productivity. Excavator used in excavation making stock piles which loaded on hauling units using the more maneuverable unit (Loader).

\section{COMMON SPEEDS OF HAULING UNITS ON HAUL ROADS}

To determine the Average speed for hauling units on terrain for both cases of maintained and unmaintained haul roads, the following $14^{\text {th }}$ question was imposed,

- What is the average speed for dump trucks for maintained / unmaintained roads?

a- For unmaintained roads:

Less than $25 \mathrm{Km} / \mathrm{Hr}$
$25-40 \mathrm{Km} / \mathrm{Hr}$
$40-60 \mathrm{Km} / \mathrm{Hr}$
More than $60 \mathrm{Km} / \mathrm{Hr}$

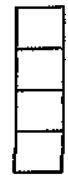

b- For maintained roads:

Less than $25 \mathrm{Km} / \mathrm{Hr}$
$25-40 \mathrm{Km} / \mathrm{Hr}$
$40-60 \mathrm{Km} / \mathrm{Hr}$
More than $60 \mathrm{Km} / \mathrm{Hr}$

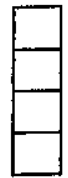

Results are agreed on ușing less than $25 \mathrm{kph}$ for unmaintained haul roads, $25-40 \mathrm{kph}$ for narrow maintained haul roads and $40-60 \mathrm{kph}$ for wide maintained haul roads, and results are represented in Figs.(13), (14). 


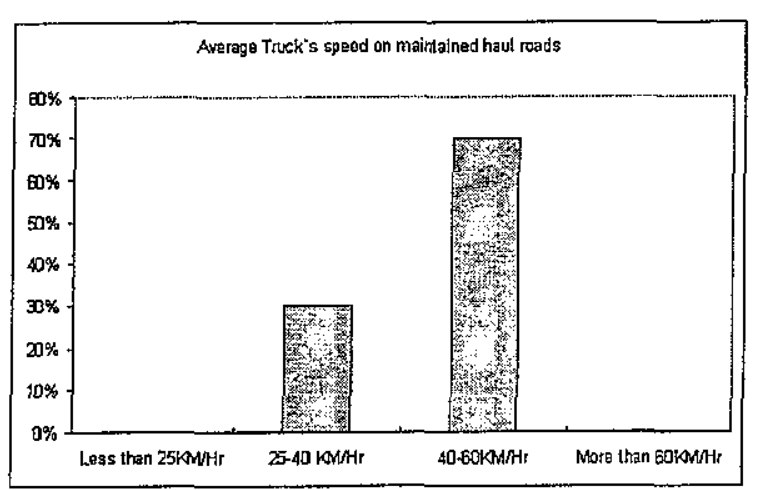

Figure (13) Average speed on maintained haul roads

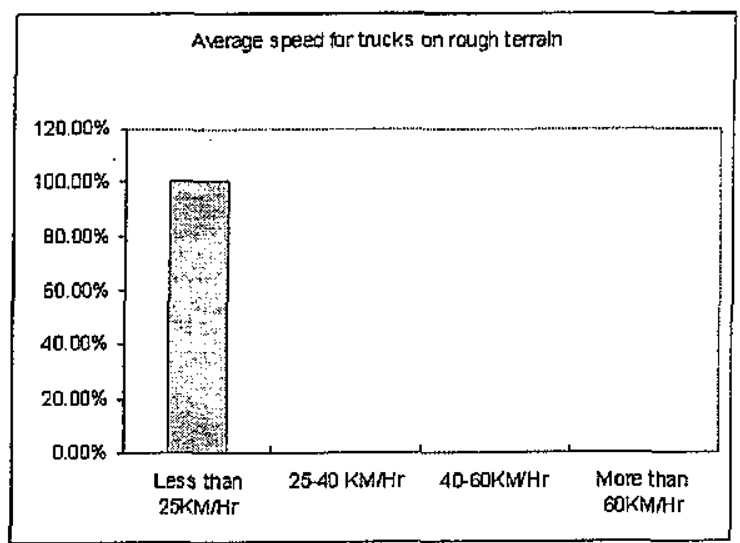

Figure (14) Average speed on rough terrain.

\section{COMMONLY USED TRADE MARKS FOR CONSTRUCTION EQUIPMENT IN IRRIGATION FIELD.}

To discover used equipment trade mark in Egypt which are used actually to study its production rate and to try to optimize its choice, $17^{\text {th }}$ question was imposed, and to determine the best trade mark in each function for different types of equipment, $18^{\text {th }}$ and $21^{\text {st }}$ questions were imposed,

- For the following equipment:

1. Elevated scrapers.

2. Back hoes.

3. Face shovels.

4. Dump trucks or Lorries.

5. Bulldozers.

6. Loaders.

7. Graders.

8. Cranes.

- What are the available trade marks in your company for the following types of equipment are they have local agent, and are the spare parts available?

(Please mention in details, all information you have about local agents)

- In your opinion what is the proposed trade marks to study its productivity through this research, to have applicable results in Egypt?

(Please mention in details, trade mark- modelproduction rate in $\left(\mathrm{m}^{3} / \mathrm{hr}\right)$ for different soil typesrental value (L.E. /hr))

- What is the best trade mark, model, for each piece of equipment, which is proposed to study its productivity and performance in details, and to have reasonable and applicable results?

According to questionnaire results the most common trade marks in descending order are: Caterpillar, Komatsu, Lybher, O\&k, Volvo, Ukled, Mercedes Benz, Magi Ross, Man Renault, Davico for trucks and Hitachi, Komatsu, Dymage, NCK, Lybher for cranes

Results are represented in Fig. (15).

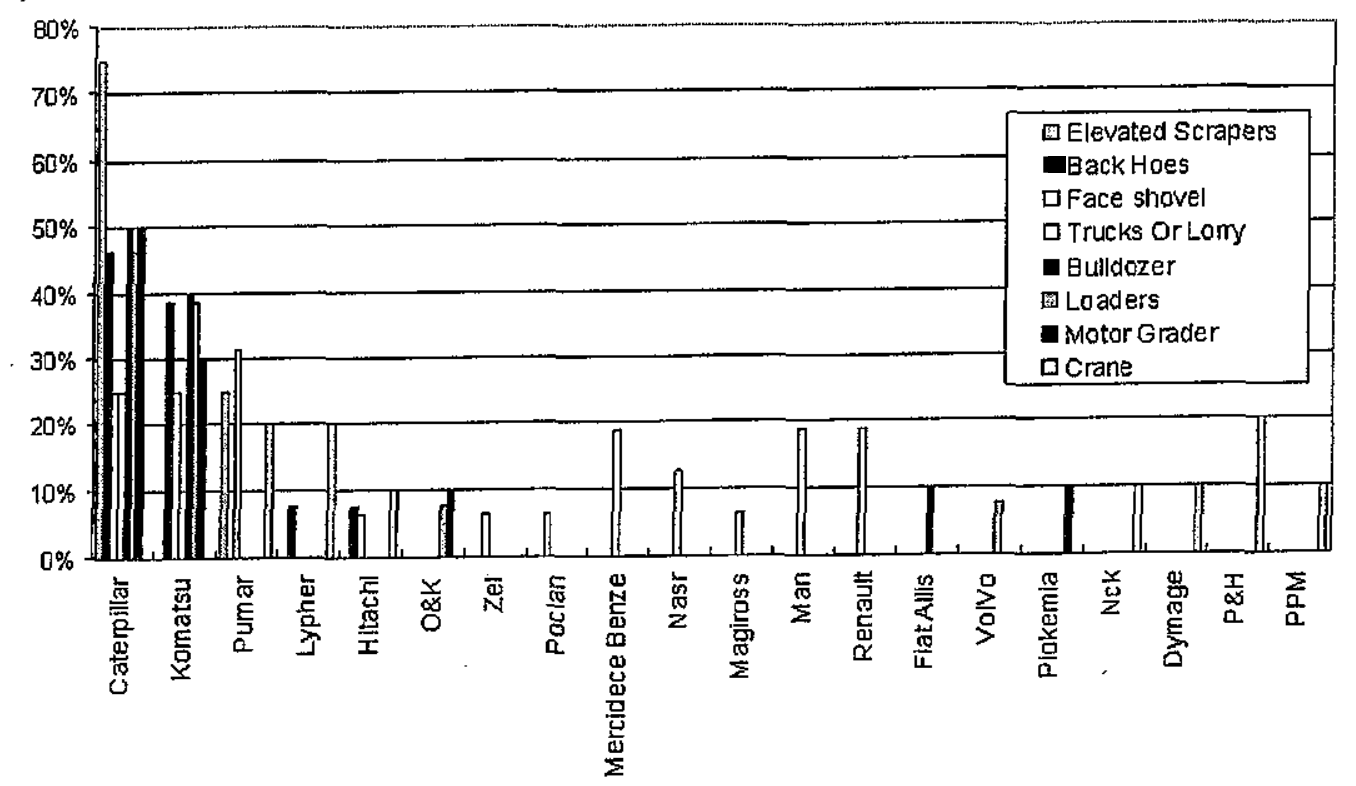

Figure (15) commonly used trade marks for construction equipment in irrigation field 


\section{BUY/RENT DECISION AND TIME EFFECT ON OPTIMUM SELECTION}

To determine reasons to buy rather than rent equipment, $19^{\text {th }}$, and $20^{\text {th }}$ questions were imposed, and to determine the relation between time constraints and choice of optimum equipment, $22^{\text {nd }}$ question was imposed, according to the following:

- Are all used equipment by your company owned or rented? (Mention in details for each type of equipment, the trade mark, model, customer, production rate in $\mathrm{m} 3 / \mathrm{hr}$, rental value in L.E. $/ \mathrm{hr}$, for:

1. Elevated scrapers.

2. Back hoes.

3. Face shovels.

4. Dump trucks or Lorries.

5. Bulldozers.

6. Loaders.

7. Graders.

8. Cranes.

- In your opinion how you decide to purchase a piece of equipment instead of rent it?

- What is the relation between time constraints and selection of optimum equipment?

Results showed that a contractor may decide to rent part or all the machinery needed for a job because of short period required to use, availability, lack of confidence in future work, lack of capital, and/or other reasons.

The contractor who keeps machinery from job to job and takes good care of it operates at lower cost than if the equipment where rented. Rental prices include an allowance for greater than average major repairs because few people are as careful of rented equipment as they are of their own, and the owner's profit is of course added in.

However, For short jobs with no sure usefullness for the machinery after completion, renting is cheaper. Contractors whose work is scattered over the country usually rent machinery at each job, instead of owning and moving it. This saves heavy transportation expense, reduces hostility to a"foreign" contractor, and makes it easier to hire and control local operators.

\section{EQUIPMENT AVERAGE RENTAL VALUES}

To determine the Average rental values per hour, day, and month for each type of equipment $3^{\text {rd }}$ question was imposed. It is found that the range is very large, because the rental value in the same firm, for the same trade mark, and the same model, may differ according to the date of its production, or purchasing date if it was before or after the buoyancy of the Egyptian pound, because equipment were purchased by U\$, or its condition if it is old or new, and number of its model type in the firm, accordingly results are very difficult to be presented graphically, so that it is shown in Tables(1) to (3).

Table (1) Equipment rental value ranges per hour.

\begin{tabular}{|l|l|}
\hline \multicolumn{1}{|c|}{ Equipment } & \multicolumn{1}{|c|}{ Rental value (L.E.)/hour } \\
\hline Elevated scrapers & $60 \& 30-50 \& 450$ \\
\hline Back Hoes & $\begin{array}{l}30-50 \& 40 \& 60 \& 70 \& 70 \& 70 \& 75 \& \\
100 \& 100\end{array}$ \\
\hline Face shovel & $30-50 \& 60 \& 60 \& 70 \& 80 \& 120 \& 150$ \\
\hline Trucks or Lorry & $20-40 \& 40 \& 40 \& 50 \& 60 \& 60$ \\
\hline Bulldozer & $\begin{array}{l}100 \& 100-120 \& 120 \& 150 \& 180 \& \\
100-200\end{array}$ \\
\hline Loader & $\begin{array}{l}40-60 \& 50 \& 50 \& 60 \& 60 \& 60 \& 70- \\
80 \& 90\end{array}$ \\
\hline Motor grader & $60 \& 80 \& 80-100 \& 100 \& 120 \& 120$ \\
\hline Cranes & $\begin{array}{l}60 \& 60 \& 80 \& 100 \& 100 \& 100-140 \& \\
100-200\end{array}$ \\
\hline
\end{tabular}

Table (2) Equipment rental rate ranges per day (One day work $=8$ hours)

\begin{tabular}{|l|l|}
\hline \multicolumn{1}{|c|}{ Equipment } & \multicolumn{1}{|c|}{ Rental value (L.E.)/day } \\
\hline Elevated scrapers & $400 \& 3000$ \\
\hline Back Hoes & $155 \& 215 \& 250 \& 400 \& 420 \& 450 \&$ \\
& $\begin{array}{l}465 \& 470 \& 500 \& 500 \& 550 \& 600 \& \\
600 \& 650 \& 700 \& 750 \& 1150\end{array}$ \\
\hline Face shovel & $250 \& 400 \& 400 \& 450 \& 560 \& 720 \&$ \\
& 1000 \\
\hline Trucks or Lorry & $155 \& 210 \& 250 \& 250 \& 250 \& 300 \&$ \\
& $320 \& 350 \& 400 \& 400 \& 450 \& 450 \&$ \\
& 600 \\
\hline Bulldozer & $680 \& 700 \& 700 \& 750 \& 750 \& 960 \&$ \\
& $1150 \& 1200 \& 1450 \& 1500 \& 1000-$ \\
& 2000 \\
\hline Loader & $300 \& 305 \& 350 \& 350 \& 400 \& 400 \&$ \\
& $400 \& 400 \& 420 \& 450 \& 500 \& 400-$ \\
& $600 \& 610 \& 630$ \\
\hline Motor grader & $420 \& 600 \& 800 \& 800 \& 1000$ \\
\hline Cranes & $250 \& 300 \& 360 \& 400 \& 400 \& 460 \&$ \\
& $500 \& 550 \& 560 \& 600 \& 600 \& 640 \&$ \\
& $700 \& 750 \& 800 \& 800 \&$ \\
& $950 \& 1000 \& 1120 \& 1175 \& 1000-$ \\
& $2000 \& 1850$ \\
\hline
\end{tabular}

Table (3) Equipment rental rate ranges per month (One month $=25$ days)

\begin{tabular}{|l|l|}
\hline \multicolumn{1}{|c|}{ Equipment } & \multicolumn{1}{c|}{ Rental value (L.E.)/month } \\
\hline Elevated scrapers & 70000 \\
\hline Back Hoes & $5000 \& 12000 \& 12000$ \\
\hline Face shovel & $7000 \& 8000 \& 22000$ \\
\hline Trucks or Lorry & $5500 \& 6000 \& 7500 \& 10000$ \\
\hline Bulldozer & $20000 \& 28000$ \\
\hline Loader & $6000 \& 8000 \& 10000 \& 10500$ \\
\hline Motor grader & $12000 \& 20000$ \\
\hline Cranes & $10000 \& 11500$ \\
\hline
\end{tabular}




\section{REPLACEMENT DECISION FACTORS}

What causes the reliance on formal analysis to remain so low?

When the survey was formulated, several questions were designed to obtain information on the recognition and weighing of factors contributing to the replacement decision, also in trying to understand the factors influencing a decision.

The status of record keeping practice was thought to be important; the $4^{\text {th }}, 5^{\text {th }}, 17^{\text {th }}$ questions were imposed to address that subject:

For the following equipment:

1. Elevated scrapers.

2. Back hoes.

3. Face shovels.

4. Dump trucks or Lorries.

5. Bulldozers.

6. Loaders.

7. Graders.

8. Cranes.

- What is the break down percentage in proportional to operating hours? For the following cases:

a- During first five operating years period,

b- Older than five years operating period.

- What is the percentage of repairing cost during its operating life according to purchasing cost, and what is the average life cycle?

- Do you perform, or have dealer service perform for you, major over hauls?

Also the following questions are discussed during several interviews to address the same subject:

- Who has final responsibility for a decision on equipment acquisition or disposition?

1. President or owner.

2. Board.

3. Equipment support

4. Others: Executive V.P.

District manager

- Are formal economic analysis undertaken in your organization to help identify optimum equipment replacement timing?

- An actual equipment replacement decision is based primarily upon:

a- Formal economic analysis.

b- Experience plus formal economic analysis.

c- Experience and informal economic analysis.

d. Other.

- Obsolescence, the fact that never model machine have increased production capacity and, therefore can accomplish an equivalent job at a lower cost is considered by many to be an equipment replacement decision consideration. At what annual rate do you estimate obsolescence occurs in production type construction equipment?
- Do you use actual maintenance and operating cost records for individual units (or groups) in making replacement decisions?

The answers to these questions suggested the reason why many companies do not employ formal analyses for equipment replacement decision making

- Contractors recognize obsolescence as a factor worthy of consideration in a machine replacement decision, but not sure of its appropriate weight.

- A correct economic replacement analysis is not possible without knowledge of the proper interest rate (cost of capital rate).

- There is evidence that as a company grows and its equipment investment is increased, its record keeping improves, our survey and a 1977 survey [10] of utility contractors noted this relationship between company size and record keeping.

\section{CONCLUSIONS}

From the results of the field study, the following results and conclusions can be summarized:

1- Based on the machine retention periods reported, it is apparent that many equipment practices are still based on judgment due to the lack of factual information and managerial knowledge concerning proper economic analysis techniques.

2- Rental rates are widely ranged. They depend on market demands, age, and condition of equipment, so taking average values in productivity calculations is considered a fatal mistake.

3- Truck -Shovel combination covers almost all site conditions, while scrapers are not used any more.

4- Caterpillar \& Komatsu are the most commonly used trade marks for Loaders and Backhoes.

5- Commonly used strategy either to use excavator, loader, truck combination, or excavator, truck combination.

\section{REFERENCES}

[1] "Caterpillar performance Hand Book", 23 edition, Oct. 1992, $32^{\text {th }}$ edition, Oct.2001.

[2] "Euclid Hauler Hand Book, Volvo Construction Equipment North America", Inc., Ashville, NC.

[3] Elammary, H.H., "Using Neural Networks in the Selection of Optimal Equipment Combinations In Construction of Irrigation Canals \& Drains", M. Sc. Thesis, College of Engineering \& Technology-Arab Academy for Science \& Technology \& Maritime Transport, December 2006.

[4] Harris, F., "Modern Construction and Ground Engineering Equipment and Methods", $2^{\text {nd }}$ 
edition, Longman Scientific and Technical, London, 1994,

[5] Jepson, D, "Marubeni Komatsu Plant Management Seminar", 2000.

[6] Nunnally, S.W, "Managing Construction Equipment", $2^{\text {nd }}$ edition, Prentice-Hall, Englewood Cliffs, NJ, 2000.

[7] Nichols H. L., David A., Day, P.E., "Moving The Earth, the work book for excavation", $4^{\text {th }}$ edition, McGraw-Hill, 1999.

[8] Peurifoy, Schnexnayder, "Construction Planning, Equipment and Methods", $6^{\text {th }}$ edition, McGraw-Hill, New York/London.

[9] Singh J., "Heavy Construction - Planning, equipment and methods", A. A. Balkema / Rotterdam, 1993.

[10] Schexnayder C.J., Hancher D.E., "Contractor Equipment - Management Practices", Journal of Construction Division, Proceedings of the American Society of Civil Engineers, ASCE, Vol. 107, No. CO4, pp 619-626, 1981.

[11] Stuart, H., Barthdomew, "Estimating and bidding for Heavy construction", Prentice-Hall, Inc., 2000.

[12] Warren D.R, "Civil Engineering Construction, Design and Management", $1^{\text {st }}$ edition, Macmillan Press Ltd, London, 1996. 